Al-Manhaj: Journal of Indonesian Islamic Family Law, 1 (2), 2019: 161-195

ISSN: 2715-003; E-ISSN 2714-5514

DOI: http://dx.doi.org/10.19105/al-manhaj.v1i2.3228

\title{
Analisis Terhadap Tingginya Nikah Siri Di Kabupaten Pamekasan
}

\author{
Akhmad Farid Mawardi Sufyan \\ (Institut Agama Islam Negeri Madura, Jl. Raya Panglegur km. 04 Pamekasan- \\ 69311, Jawa Timur, Indonesia)
}

\begin{abstract}
Abstrak
Ikatan Perkawinan mempunyai arti penting dalam kehidupan manusia. Seiring dengan perkembangannya karena sah dan tidaknya suatu perkawinan sesuai dengan agamanya maka kawin siri sangat marak dan menjadi ngetrend. Ini adalah penelitian normatif - lapangan. Menurut UU. No. 1/1974, Perkawinan adalah sah apabila dilakukan menurut hukum masing-masing agamanya dan kepercayaannya itu. Faktor utama dilakukan nikah siri karena ketidakpahaman \& pola pikir masyarakat di Kabupaten Pamekasan terhadap pentingnya perkawinan yang dicatatkan, fungsi serta akibat hukum yang timbul di masa mendatang. Pemkab Pamekasan bersama perangkat Kantor Urusan Agama menyelenggarakan program nikah massal secara ekonomis sebagai solusi menekan angka nikah siri. (Marriage ties have an important meaning in human life. Along with its development because it is legal and whether a marriage is in accordance with its religion, siri marriage is very lively and becomes popular. This is normative - field research. According to the law. No. 1/1974, Marriage is legal if it is done according to the law of each of its religions and beliefs. The main factor is the marriage of siri because of the misunderstanding \& mindset of the people in Pamekasan Regency regarding the importance of registered marriages, functions and legal consequences that arise in the future. Pamekasan Regency Government together with the Office of Religious Affairs organizes a mass marriage program economically as a solution to reduce the number of siri marriage
\end{abstract}

Kata Kunci:

Nikah Siri;Hukum;Pamekasan 


\section{Pendahuluan}

Ritual perkawinan di kabupaten Pamekasan Madura tidak hanya dipandang sebagai peristiwa sakral. Ikatan perkawinan adalah bagian penting dalam membentuk keluarga yang harmonis dan penuh rasa cinta kasih. Seorang pria dan wanita yang dulunya merupakan pribadi yang bebas tanpa ikatan hukum, namun setelah perkawinan menjadi terikat secara lahir maupun batin sebagai suami isteri. Jalinan yang ada diantara mereka merupakan ikatan lahiriah, rohaniah, spiritual dan kemanusiaan. Ikatan perkawinan ini menimbulkan akibat hukum terhadap diri masing-masing suami isteri yang berupa hak dan kewajiban.

Kabupaten Pamekasan terdiri dari 13 kecamatan yang terbagi menjadi dua zona Pamekasan selatan dan pantura (pantai utara), Pamekasan Selatan dikenal dengan daerah pinggiran kota dan sebagian besar masyarakatnya berpendidikan sedangkan daerah pantura sebagian besar masyarakatnya tidak berpendidikan. Praktik nikah siri terbanyak di wilayah utara Pamekasan. Seperti di wilayah Kecamatan Batumarmar, Pasean, Waru, Pakong, Pegantenan dan Kecamatan Proppo.

Seiring dengan perkembangannya karena sah dan tidaknya suatu perkawinan sesuai dengan agamanya maka kawin siri sangat marak dan menjadi ngetrend. Baik politisi, pengusaha, kyai dan orang biasa/masyarakat pada umumnya di Kabupaten Pamekasan Madura. Bahkan ada yang malah bermaksud mengadukan perkara ke pengadilan perihal satu pihak merasa tidak pernh sekalipun melakukan kawin siri sedangkan pihak yang lain melakukan klaim bahwa ia telah melakukan perkawinan tersebut.

Berdasarkan latar belakang di atas maka terdapat dua permasalahan dalam penelitian ini, Apakah yang melatarbelakangi masyarakat melakukan nikah siri di Kabupaten Pamekasan? Bagaimanakah upaya pemerintah kabupaten Pamekasan dalam meminimalisir terjadinya nikah siri?

\section{Metode Penelitian}

Ini adalah penelitian normatif ${ }^{1}$ dengan pendekatan lapangan. Penelitian ini menjawab pertanyaan yang diungkapkan dalam

1 Abdulkadir Muhammad, Hukum dan Penelitian Hukum, Bandung, Citra Aditya bakti, 2004, hal. 157 
penelitian ini dengan melihat peraturan perundang-undangan yang ada lalu membandingkan langsung pelaksanaannya di lapangan.

Secara umum penelitian ini dilakukan di Pamekasan. Namun secara khusus akan dilakukan di enam kecamatan, yakni kecamatan Batumarmar, Pasean, Waru, Pakong, Pegantenan dan Proppo. Dipiihnya beberapa daerah tertentu dimaksud karena asumsi tingginya nikah siri di beberapa kecamatan tersebut.

Data yang diperoleh dari kepustakaan dan lapangan, dianalisis secara deskriptif - kualitatif, karena data-data yang ada dikumpulkan berdasarkan temuan data di lapangan, lalu dikatakan bersifat kualitatif karena data tersebut didapat melalui interview dengan para informan, agar dapat menjelaskan atau menjawab poin permasalahan yang diutarakan dalam penelitian ini secara terbuka.

\section{Kajian Teoritik Nikah Siri}

A. Konsep Nikah dalam Perspektif Fiqh dan Hukum Positif ${ }^{2}$

Pembahasan Nikah biasanya pembahasan yang ketiga dalam literatur Fiqh. ${ }^{3}$ Nikah adalah syariat masa lampau karena ia dilakukan sejak masa nabi Adam as. dan berkelanjutan hingga kelak di surga. ${ }^{4}$ Nikah hukumnya sunnah bagi orang yang merasa butuh. Sebagaimana yang telah dijelaskan oleh ayat :

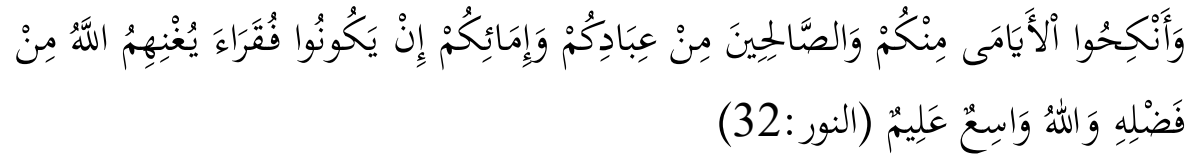

Dan kawinkanlah orang-orang yang sedirian di antara kamu, dan orang-orang yang layak (berkawin) dari hamba-hamba sahayamu yang lelaki dan hamba-hamba sahayamu yang perempuan. Jika mereka miskin Allah

2 Pengertian hukum islam kini mengalami generalisasi. Yang pertama bisa berarti fiqh (murni). Yang kedua bisa bermakna fiqh yang sudah diadopsi menjadi hukum positif indonesia yang sudah melebur ke dalam peraturan perundang-undangan.

${ }^{3}$ Ibrahim al-Bajuri, Syarh Fath Al-Qarib, Surabaya : al-Hidayah, tt, II, 244

${ }^{4}$ Muhammad Syatha al-Dimyati, I'anah al-Thalibin, Juz III, 253 
akan memampukan mereka dengan kurnia-Nya. Dan Allah Maha luas (pemberian-Nya) lagi Maha Mengetahui. (QS. An-Nur : 32) ${ }^{5}$

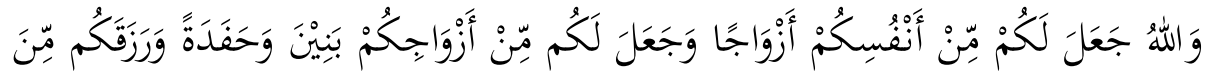

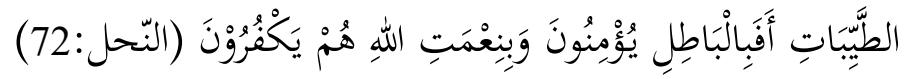

Allah menjadikan bagi kamu istri-istri dari jenis kamu sendiri dan menjadikan bagimu dari istri-istri kamu itu, anak-anak dan cucu-cucu, dan memberimu rezeki dari yang baik-baik. Maka mengapakah mereka beriman kepada yang batil dan mengingkari nikmat Allah?" (QS. Al-Nahl:72 ) ${ }^{6}$

Dalam ayat lain juga ditegaskan :

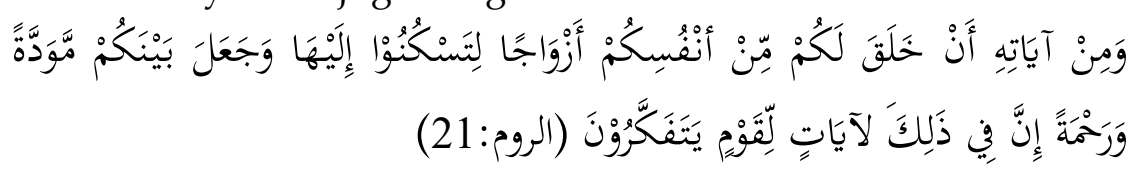

Dan di antara tanda-tanda kekuasaan-Nya ialah Dia menciptakan untukmu istri-istri dari jenismu sendiri, supaya kamu cenderung dan merasa tenteram kepadanya, dan dijadikan-Nya di antaramu rasa kasih dan sayang. Sesungguhnya pada yang demikian itu benar-benar terdapat tandatanda bagi kaum yang berpikir. (QS. Al-Rum/30:21) ${ }^{7}$

Hadits Nabi SAW:

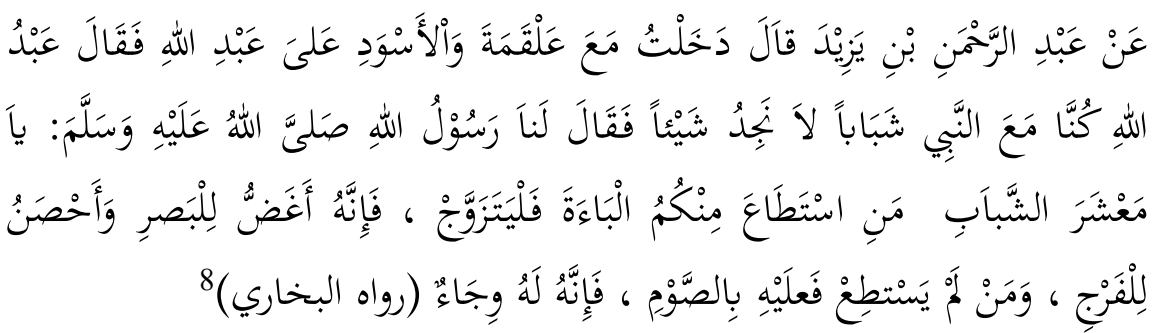

${ }^{5}$ Adapun maksudnya: hendaklah laki-laki yang belum kawin atau wanita-wanita yang tidak bersuami, dibantu agar mereka dapat kawin. Kementerian Agama, Al-Qur'an dan Terjemahnya, 355

${ }^{6}$ Kementerian Agama, Al-Qur'an dan Terjemahnya, Bandung : alJumanatul Ali, 2005, 275

${ }^{7}$ Kementerian Agama, Al-Qur'an dan Terjemahnya, 407

${ }^{8}$ Muhammad al-Bukhari, Sahih al-Bukhari, Maktabah Syamilah, V, 1950. Ibn Hajr 'Asqalani, Bulugh al-Maram, Surabaya : Alhidayah, tt, 200. Hadits ke 993; Badruddin al-Aini, Umdah al-Qariy Syarhu Shahih al-Bukhari, Maktabah Syamilah, tt, XXIX, 182). 
Dari Abdullah bin Mas'ud ra. Berkata : Rasulullah SAW bersabda kepada kami: wahai para pemuda. Barang siapa di antara kamu sekalian mampu (melakukan) nikah, maka kawinlah. Karena sesungguhnya ia dapat memejamkan pandangan dan menjaga kehormatan. Dan barang siapa yang tidak mampu maka wajib baginya berpuasa karena dengan (puasa)itu ia terpelihara. (HR Bukhari)

Sedangkan definisi nikah dapat dipaparkan di bawah ini:

Nikah adalah akad yang berakibat kebolehan melakukan hubungan seksual dengan menggunakan lafad "inkah/ menikahkan". ${ }^{9}$ Perkawinan : ikatan lahir bathin antara seorang pria dengan seorang wanita sebagai suami isteri dengan tujuan membentuk keluarga (rumah tangga) dan kekal berdasarkan Ketuhanan Yang Maha Esa. ${ }^{10}$ Perkawinan menurut hukum islam adalah pernikahan, yaitu akad yang sangat kuat atau mitsaqan ghalidzan untuk mentaati perintah Allah dan melaksanakannya merupakan ibadah. ${ }^{11}$

Rukun Nikah

Rukun nikah ada lima, yakni calon suami, calon isteri, wali, saksi dan sighat ${ }^{12}$, yang Penjabarannya dijelaskan di bawah ini :

1. Calon suami. Seorang suami harus muslim, bila wanita yang akan dinikahi adalah seorang muslimah. Jika si suami adalah seorang non muslim dan si wanita adalah muslimah, maka pernikahannya batal. Al-Qur'an menjelaskan:

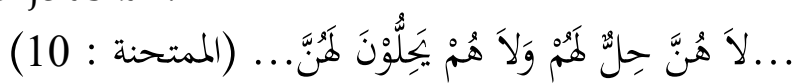

Mereka (Perempuan Muslimah) tiada halal bagi orang-orang kafir itu dan orang-orang kafir itu tiada halal pula bagi mereka. (QS. AlMumtahanah : 10) ${ }^{13}$ 97-98

9 Zain al-Din al-Malibari, Fath al-Mu'in, (Surabaya : al-Hidayah, tt),

10 Tim penyusun, Undang-Undang Perkawinan, H. 1-2. Pasal 1

11 Tim penyusun, Kompilasi Hukum Islam, Instruksi Presiden Nomor 1 Tahun 1991, H.14. pasal 2

12 Zakariya al-Anshari, Hasyiyah al-Jamal, (al-Maktabah al-Syamilah, tt) Juz XVI, H. 306

${ }^{13}$ Departemen Agama RI., Al-Qur'an dan Terjemahnya, H. 551 
Selain itu calon suami harus memenuhi kriteria-kriteria berikut :

a. Menikah berdasarkan kemauannya sendiri tanpa ada paksaan dari orang lain.

b. harus jelas dan tertentu. Sehingga tidak sah menikahnya salah seorang dari dua orang lelaki tanpa ada lebih dulu jelas lelaki yang mana yang akan menikah.

c. harus tahu terhadap nama perempuan yang akan dinikahinya, atau nasabnya atau dirinya dan status kehalalannya. tidak sah nikahnya lelaki yang yang sedikitpun tidak tahu perihal calon istrinya.

d. harus laki-laki secara pasti. Dengan ini tidak sah nikahnya lakiseorang banci walaupun setelah akad nikah ia terbukti status jenis kelamin bahwa ia laki-laki. ${ }^{14}$

2. Calon istri, Baginya disyaratkan beberapa hal berikut:

a. harus halal untuk dinikahi. Berarti tidak sah menikahi wanita yang masih ikatan mahram.

b. harus tertentu dan jelas

c. tidak sedang dalam ikatan pernikahan denga pria lain, atau masa iddah.

d. harus seorang perempuan secara pasti. Dengan ini tidak sah nikahnya waria walaupun setelah akad status kewanitaannya terbukti. ${ }^{15}$

3. Wali serta 2 saksi laki-laki. akad nikah tidak sah kecuali dengan hadirnya seorang wali laki-laki dan dua orang saksi yang adil. Wali dan dua saksi tersebut enam syarat:

a. Islam

b. Laki-laki

c. Berakal

d. Baligh (dewasa)

e. Merdeka

f. Adil ${ }^{16}$

\footnotetext{
${ }^{14}$ Muhammad Amin al-Kurdy, Tanwir al-Qulub Fi Mu'amalah 'Allamil Uyub, (Jakarta : an-Nur, tt) H. 343

15 al-Kurdy, Tanwir al-Qulub, H. 345

${ }^{16} \mathrm{Abu}$ Bakar Muhammad al-Husaini, Kifayah al-Akhyar, al-Maktabah al-Syamilah, tt, III, 4
} 
4. Sighat ${ }^{17}$. Atau ijab kabul. Ijab adalah ucapan wali زَنْحَنُُْكَ (yang bermakna: aku menikahkan kepadamu), yang kemudian

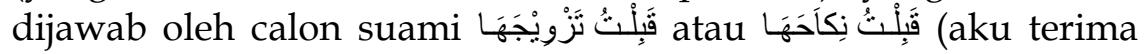
nikahnya pihak perempuan). ${ }^{18}$ Akad ini sah walaupun diucapkan oleh orang yang bergurau. ${ }^{19}$

Faktor Pendorong Nikah

Faktor-faktor yang mendorong untuk melakukan pernikahan Pembahasannya sangat dekat dengan kajian tentang anjuran-anjuran untuk melakukan pernikahan. Oleh karena itu dibawah ini akan dipaparkan tentang kedua-keduanya hingga pembahsannya tuntas dan komprehensif.

1. Tuntutan Naluri Sosiologis.

Sosiolog dan sejarawan besar muslim Ibnu Khaldun mengatakan bahwa manusia itu adalah makhluk sosial yang terbawa oleh naluri dan tabiatnya, yakni dia tidak bisa berdiri sendiri, justru membutuhkan yang lain paling minim dia membutuhkan istri yang mendampinginya. ${ }^{20}$ Rum : 21:

Dalam konsep ini Allah SWT telah berfirman dala surat Al-

Dan di antara tanda-tanda kekuasaan-Nya ialah Dia menciptakan untukmu istri-istri dari jenismu sendiri, supaya kamu cenderung dan merasa tenteram kepadanya, dan dijadikan-Nya di antaramu rasa kasih dan sayang. Sesungguhnya pada yang demikian itu adalah benar-benar terdapat tanda-tanda bagi kaum yang berpikir. ${ }^{21}$

17 Kementerian Wakaf dan Urusan Agama Kuwait, al-Mausu'ah alFiqhiyyah, Maktabah Syamilah, tt, II, 10055; KH. Adib Bisri \& KH. Munawwir, Kamus al-Bisri, Surabaya : Putaka Progresif, 1999, 423

${ }^{18}$ Al-Nawawi, Raudlah ath-Thalibin Wa 'Umdah al-Muftin,Maktabah Syamilah, tt, II, 460

H. 118

${ }^{19}$ Al-Bujairimi, Hasyiyah al-Bujairimi, Maktabah Syamilah, tt, Juz 10

20 Hasan Baharun, Islam Esensial: Kajian Membumikan Sunnah Rasulullah, (Jakarta : Pustaka Awam, 1998), 154-155

${ }^{21}$ Departemen Agama RI, Al-Qur'an dan Terjemahnya, H. 407. AlMawardi mengemukakan bahwa yang dimaksud pada potongan ayat : Dan di antara tanda-tanda kekuasaan-Nya ialah Dia menciptakan untukmu istriistri dari jenismu sendiri, Ada dua pengertian. Pertama, adalah Siti Hawa 


\section{Untuk Melestarikan Keturunan}

Pernikahan merupakan perantara bagi manusia yang berakal untuk menjaga dan mengekalkan jenis kelaminnya dengan cara beranak cucu dan berketurunan.22 Dalam al-Qur'an surat al-Nahl: 72 yang artinya

Allah menjadikan bagi kamu istri-istri dari jenis kamu sendiri dan menjadikan bagimu dari istri-istri kamu itu, anak-anak dan сuсu-cucu, dan memberimu rezeki dari yang baik-baik. Maka mengapakah mereka beriman kepada yang batil dan mengingkari nikmat Allah? ${ }^{23}$

yang diciptakan dari tulang rusuk Nabi Adam as. Pengertian Kedua adalah penciptaan Tuhan terhadap semua pasangan dari jenis-jenis mereka sendiri. Baik itu laki-laki maupun perempuan seperti yang dijelaskan oleh Ali bin Isa. (Lihat: Ali ibn Muhammad al-Mawardi, an-Nukat wal 'Uyun, Maktabah al-Syamilah, Juz III, H. 315)

Pengertian pertama di atas banyak mendominasi tafsir ayat ini, meskipun ada sebagian yang memberikan pengertian yang lebih komprehensif. (Lihat: Imam ath-Thabri, Tafsir ath-Tabri, (al-Maktabah alSyamilah) Juz 20 Hal 86; Jalaluddin Muhammad al-Mahally dan Jalaluddin Abdur Rahman as-Suyuty, Tafsir al-Qur'an Lil Imamaini al-Jalalaini, (Indonesia : Dar Ihya' al-Kutub al-Arabiyah), H. 335; Az-Zamakhsyari, Tafsir alKasysyaaf, (al-Maktabah al-Syamilah), Juz V, H. 243; al-Baidlawi, Tafsir alBaidlawi, (al-Maktabah al-Syamilah), Juz IV, H. 481)

Selanjutnya, pada penggalan ayat "Supaya kamu cenderung dan merasa tenteram kepadanya, mengandung pengertian supaya merasa bersenang hati bersama pasangannya. Karena sesungguhnya dari rasa senang (al-unsiyah) itu, Allah menjadikan (untuk pasangan itu) sesuatu yang tidak diciptakan kecuali bagi kedua mempelai tersebut.

Pada ayat selanjutnya "dan dijadikan-Nya di antaramu rasa kasih dan sayang", al- Mawardi mengungkapkan bahwa dalam kata "Mawaddah" dan "Rahmah" memiliki empat pengertian. (1) Mawaddah adalah rasa cinta dan rahmah adalah kasih sayang; (2) mawaddah adalah jima' (senggama) dan rahmah adalah anak; (3) mawaddah adalah mencintai yang lebih tua, dan rahmah adalah Menyayangi yang lebih muda; (4) yang dimaksud dengan mawaddah wa rahmah tersebut adalah sikapa yang saling menyayangi diantara kedua suami isteri. (Lihat: al-Mawardi, an-Nukat wal 'Uyun, Juz III, 315)

${ }^{22}$ Abu Hadian S, Hak-hak Anak dalam Syariat Islam; Dari Janin hingga Pasca Kelahiran, 13-14

${ }^{23}$ Kementerian Agama, Al-Qur'an dan Terjemahnya, 275 
Berdasarkan ayat diatas, ditegaskan bahwa Allah telah menjadikan bagi masing-masing manusia pasangan-pasangan yang kemudian akan melahirkan keturunan, anak cucu. Bahkan sejarah mencatat bahwa nabi-nabi terdahulu berdoa meminta kepada Tuhan supaya diberi keturunan. ${ }^{24}$ Disebutkan dalam al-Qur'an kisah nabi Zakaria :

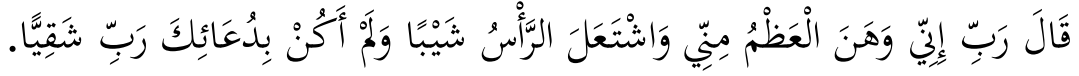

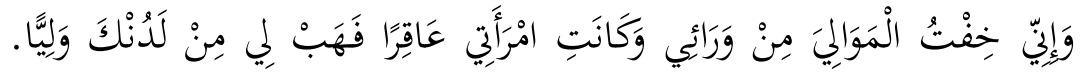

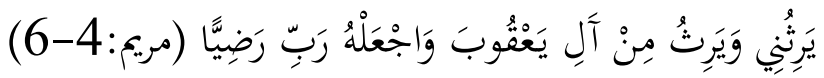

Ia berkata "Ya Tuhanku, sesungguhnya tulangku telah lemah dan kepalaku telah ditumbuhi uban, dan aku belum pernah kecewa dalam berdoa kepada Engkau, ya Tuhanku. Dan sesungguhnya aku khawatir terhadap mawaliku sepeninggalku, sedang isteriku adalah seorang yang mandul, maka anugerahilah aku dari sisi Engkau seorang putera, Yang akan mewarisi aku dan mewarisi sebahagian keluarga Ya'qub; dan jadikanlah ia, ya Tuhanku, seorang yang diridhai." (QS: Maryam:4-6)25

Tiga penggal kalimat di atas adalah doa yang dipanjatkan oleh nabi Zakaria kepada Tuhan supaya dirinya diberi keturunan untuk melanjutkan perjuangannya dan terjaganya keturunan darinya. Hal ini menunjukkan bahwa jika manusia tidak memiliki keturunan akan dilanda keresahan tanpa memandang siapapun tidak terkecuali seorang nabi seperti nabi Zakariya. Sehingga tidaklah salah jika faktor pendorong nikah adalah melestarikan keturunan.

Dengan memiliki keturunan, menurut al-Ghazali akan tercapai setidak-tidaknya 4 hal:

a. Selarasnya kecintaan kepada Allah dengan berusaha melahirkan anak demi melestarikan spesies (jenis) manusia di muka bumi.

b. Tuntutan kecintaan kepada Rasulullah SAW dengan membuat beliau bangga dengan banyaknya keturunan dari umatnya. ${ }^{26}$

24 Nada Abu Ahmad, Engkaulah Pendamping Yang Aku Cari, Solo: Pustaka Iltizam, 2007, 29

${ }^{25}$ Kementerian Agama, Al-Qur'an dan Terjemahnya, 306

${ }^{26} \mathrm{Hal}$ ini sebagaimana penuturan (hadits) Rasul SAW bahwa beliau akan merasa bangga dengan banyaknya jumlah umat beliau yang jumlahnya melebuhi jumlah umat-umat nabi yang lain kelak pada hari kiamat. (Lihat: 
c. Meminta keberkahan dengan perantara doa anak yang salih sesudahnya ${ }^{27}$

d. Meminta syafaat dengan meninggalnya anak kecil yang mati jika meninggal sebelum kedua orang tuanya. 28

e. Memenuhi kebutuhan biologis secara sehat.

Pernikahan adalah sarana legal yang telah diajarkan Tuhan kepada manusia untuk menyalurkan hasrat biologis yang manusiawi secara halal. Al-Qur'an mengibaratkan bahwa istri adalah ladang yang bisa dimanfaatkan untuk bercocok tanam, untuk suami yang memiliki benih yang mesti disalurkan. Dalam bahasan ini al-Qur'an menegaskan:

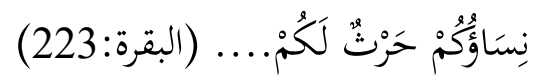

Isteri-isterimu adalah (seperti) tanah tempat kamu bercocok tanam.(QS. Al-Baqarah : 233)29

Selain itu menyalurkan biologis dengan pernikahan jauh lebih sehat daripada menyalurkannya di luar nikah. Fakta yang berkembang hingga kini adalah penyakit HIV / AIDS yang diidap oleh mereka yang suka berganti-ganti pasangan dan melakukan seks pra nikah. Padahal berganti-ganti pasangan adalah perilaku menyimpang menurut agama. Karena Selain dilarang juga tidak baik bagi kesehatan. Dengan nikah manusia diharapkan lebih menjaga pandangannya dan memelihara kehormatan. Dari sekian manfaat nikah yang paling urgen dan prinsipil hanya tiga hal yang telah disebutkan di atas.

Beban Pernikahan

Sulaiman bin al-Asy-'ab Abu Dawud,, Sunan Abu Dawud, Juz VI, Hal, 228) Secara singkat Bunyi hadits tersebut adalah :

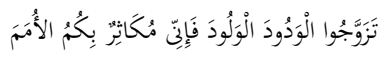

27 Maksudnya jika kelak si orang tua meninggal dunia memiliki, maka anak akan medoakan mereka. Disaat semua amal putus, maka doa anak salih inilah yang kemudian mendatangkan keberkahan. (Lihat: Muslim ibn Hajjaj, Shahih Muslim, Maktabah Syamilah, tt, Juz XI, H. 68)

${ }_{28}$ Muhammad al-Ghazali, Ihya' Ulum al-Din, (Semarang : Karya Toha Putera, tt) Juz II, H. 25

${ }^{29}$ Departemen Agama RI, Al-Qur'an dan Terjemahnya, H.38 
Setelah akad (Ijab Qabul) nikah selesai dilakukan maka si suami akan dibebani tanggung jawab yang harus dipenuhi. Tanggung jawab yang awalnya menjadi beban orang tua atau wali, lalu berpindah tangan menjadi tanggung jawab suami. Tanggung jawab itu dapat peneliti uraikan secara garis besar di bawah ini:

1. Memberikan Mahar.

Mahar adalah sesuatu yang harus ditunaikan oleh seorang suami saat ia telah menikahi seorang wanita. Kewajiban ini berlaku baik sudah menggauli istri atau belum. Kewajiban ini didasarkan pada al-Qur'an surat an-Nisa' ayat: 4. :

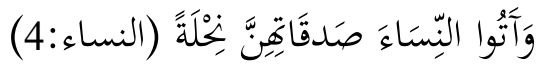

Berikanlah mahar (maskawin) kepada wanita (yang kau nikahi) sebagai pemberian dengan penuh kerelaan.. (QS. An-Nisa':4)

Penyerahan mahar (Maskawin) ini adalah salah satu dari usaha Islam, yaitu memperhatikan dan menghargai kedudukan wanita, memberinya hak untuk memegang urusannya. ${ }^{30}$

2. Tanggung jawab memberi nafkah yang secukupnya, baik lahir maupun batin.

Seorang suami wajib memberi nafkah kepada istrinya. Baik itu nafkah lahir maupun nafkah bati. Nafkah lahir dalam artian memenuhi segala kebutuhan primer sang istri serta anak-anaknya, meliputi kebutuhan pangan, sandang dan papan.

Nafkah batin meliputi pemenuhan kebutuhan seksual. Seorang suami harus mampu memenuhinya. Terlebih lagi pemenuhan seksual secara legal menjadi faktor pendorong nikah. Jika hal ini tidak terpenuhi bisa menjadi petaka rumah tangga. Karena jika faktor kebutuhan biologis tidak terpenuhi, pasti seseorang akan melampiaskannya dengan berbagai cara. Kalau saja tidak tertanam keimanan yang kuat mungkin saja berlanjut pada hubungan serong atau perselingkuhan dengan orang lain.

Dalam fiqih pun bila seorang suami atau istri tidak bisa menjalankan peranannya secara biologis, bisa diajukan kepada hakim untuk meminta keputusan cerai. Dan ini secara hukum legal formal

${ }^{30}$ M. Afnan Chafidh dan A. Ma'ruf Asrori, Tradisi Islami, (Surabaya : Khalista, 2006), Cet. I, h. 160 
dibenarkan dalam konteks hukum perundang-undangan positif indonesia.

3. Mendidik akhlak dan agama dengan baik.

Kewajiban ini berpijak pada posisi suami dalam rumah tangga yang berkedudukan sebagai pemimpin rumah tangga. Hal ini sudah ditegaskan oleh Allah dalam firmannya:

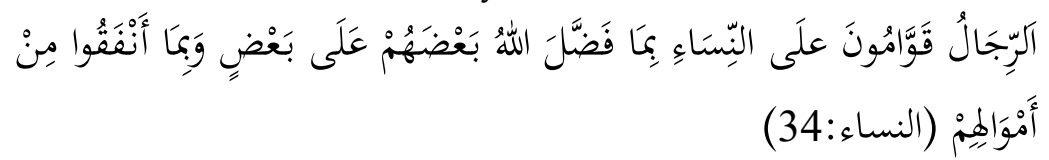

Golongan laki-laki itu adalah pemimpin bagi kaum wanita, oleh karena Allah telah melebihkan sebahagian mereka (laki-laki) atas sebahagian yang lain (wanita), dan karena mereka (laki-laki) telah menafkahkan sebagian dari harta mereka. (al-Nisa' : 34) ${ }^{31}$

Menurut al-Mawardi ayat di atas memiliki setidaktidaknya ${ }^{32}$ tiga pengertian:

a. Dalam rumah tangga, suami adalah pemimpin bagi keluarganya. Sehingga dengan posisinya sebagai pemimpin ia harus berlaku bijak dalam setiap perlakuannya terhadap istri dan anak-anaknya. Termasuk kewajiban suami adalah mendidik istri dan anaknya.

b. Dalam hal kepemimpinannya itu suami hendaknya memimpin dengan menggunakan kelebihan dari Allah yang dimiliki oleh suami. Kelebihan itu adalah rasio dan pendapat atau pendangan.

c. Posisi suami sebagai pemimpin merupakan implikasi kewajiban mereka dalam memberikan mahar dan kecukupan hidup. ${ }^{33}$

Selain itu kewajiban suami dalam kapasitasnya sebagai pemimpin adalah Mengayomi, melindungi kehormatan dan keselamatan istrinya. Ini dalam artian menjaga secara fisik terlebih

${ }^{31}$ Departemen Agama RI, Al-Qur'an dan Terjemahnya, h. 84

32 Peneliti memilih untuk menggunakan "setidak-tidaknya" karena keagungan al-Qur'an yang maknanya tidak hanya satu, dua atau tiga saja. Jika dilakukan perenungan yang lebih intens dengan pergumulannya dengan sains dan realitas, bukan tidak mungkin jika mendapatkan makna dan penafsiran baru.

33 Ali ibn Muhammad al-Mawardi, al-Nukat wa al-Uyun, Juz I, Hal 294 
lagi secara syariat. Menjaga secara fisik berarti menjaga dari segala bentuk kekerasan, pelecehan dan penganiayaan. Menjaga secara syariat artinya menjaga dari api neraka dengan menyuruh istri dan anaknya melakukan semua kewajiban agama dan menjauhkan mereka dari melakukan perbuatan-perbuatan yang melanggar agama. Hal ini sebagaimana termaktub dalam firman Allah yang berbunyi :

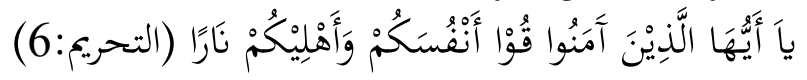

Hai orang-orang yang beriman, peliharalah dirimu dan keluargamu dari api neraka (QS. at-Tahrim : 6) ${ }^{34}$

Dan penting diketahui bahwa setiap pemimpin akan dimintai pertanggungjawabannya kelak di akhirat. Sebagaimana dalam hadits Nabi SAW:

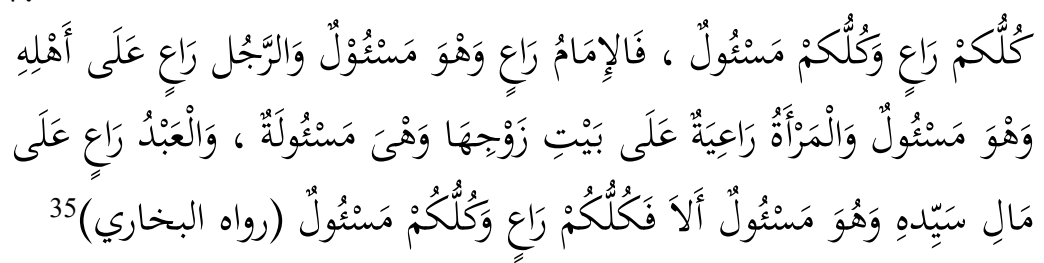

Setiap kamu sekalian adalah pemimpin dan setiap kalian akan diminta pertanggung jawaban. Maka seorang imam adalah pemimpin dan akan diminta pertanggung jawaban. Seorang suami adalah pemimpin bagi keluarganya dan dia akan diminta pertanggung jawabannya. Seorang istri adalah pemimpin bagi rumah suaminya dan dia akan diminta pertanggung jawaban. Dan Seorang budak adalah pemimpin bagi harat tuannya dan dia akan dimintai pertanggung jawaban. Ingatlah bahwa setiap kamu sekalian adalah pemimpin dan kamu sekalian akan diminta pertanggung jawaban. (HR. Bukhari)

\section{Pencatatan Nikah}

Dalam hukum positif Indonesia, Masalah kedudukan anak diatur dalam Undang-undang Nomor 1 Tahun 1974 tentang pokokpokok perkawinan, yaitu pada bab IX pasal 42 sampai 47. Pasal 42 mengatakan, anak yang sah adalah anak yang dilahirkan di dalam atau sebagai akibat perkawinan yang sah. Sementara perkawinan

34 Departemen Agama RI, Al-Qur'an dan Terjemahnya, h. 561

35 Muhammad ibn Ismail al-Bukhari, Shahih al-Bukhari, Juz XVII, H. 291. Hadits ke 5188 
yang sah itu, adalah perkawinan yang memenuhi syarat yang diatur dalam pasal 2 undang-undang pokok perkawinan. Menurut pasal itu perkawinan yang sah adalah perkawinan yang dilakukan menurut hukum masing-masing agama dan kepercayaannya, serta dicatatkan menurut peraturan perundang-undangan yang berlaku. ${ }^{36}$

Anak yang dilahirkan di luar perkawinan sesuai pasal 43 ayat (1) Undang-undang Nomor 1 Tahun 1974, hanya mempunyai hubungan perdata dengan ibunya. Artinya dia tidak mempunyai hubungan hukum dengan ayahnya. Demikianpun suami dapat menyangkal sahnya anak yang dilahirkan istrinya. Bilamana ia dapat membuktikan bahwa istrinya telah berzina, dan anak itu akibat perbuatan zina. Dalam keadaan demikian masalahnya akan diputuskan oleh pengadilan.

Sekarang, dengan ditetapkannya Peraturan pemerintah (PP) No. 19 tahun 2015 maka biaya nikah bisa dilakukan dengan Rp. 0,atau gratis. Selama akad nikah dilakukan di Kantor Urusan Agama (KUA). Hal ini dijelaskan dalam pasal 5 sebagaimana paparan di bawah ini:

\section{Pasal 5}

(1) Setiap warga Negara yang melaksanakan nikah atau rujuk di Kantor Urusan Agama Kecamatan atau di luar Kantor Urusan Agama Kecamatan sebagaimana dimaksud dalam Pasal 1 ayat (1) huruf $b$ tidak dikenakan biaya pencatatan nikah atau rujuk.

(2) Dalam hal nikah atau rujuk dilaksanakan di luar Kantor Urusan Agama Kecamatan dikenakan biaya transportasi dan jasa profesi sebagai penerimaan dari Kantor Urusan Agama Kecamatan sebagaimana ditetapkan dalam Lampiran Peraturan Pemerintah ini.

(3) Terhadap warga Negara yang tidak mampu secara ekonomi dan/atau korban bencana yang melaksanakan nikah atau rujuk di luar Kantor Urusan Agama Kecamatan sebagaimana dimaksud pada ayat (2) dikenakan tarif Rp 0,00 (nol rupiah). ${ }^{37}$

\footnotetext{
${ }^{36}$ Darwan Prinst, Hal.88-89
}

37 Peraturan Pemerintah (PP) Republik Indonesia No. 19 tahun 2015 tentang jenis dan tarif atas jenis penerimaan negara bukan pajak yang berlaku pada Kementerian Agama. 
B. Al-Mashlahah al-Mursalah

Al-Mashlahah al-Mursalah adalah :

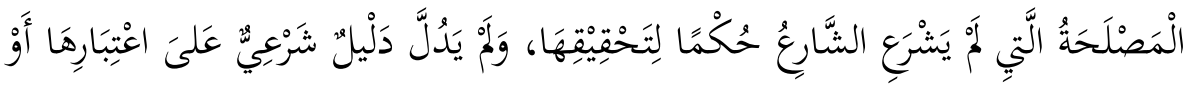

$$
\begin{aligned}
& \text { إلْغَائهَها. }
\end{aligned}
$$

"Kemaslahatan yang tidak disyariatkan dalam bentuk hukum oleh syari' dan tidak ada dalil yang mendukung atau menolaknya."

Sebagaimana fungsi dan tujuan aksiologis dibentuknya hukum Islam (fikih) adalah untuk mewujudkan kemaslahatan bagi manusia. ${ }^{39}$ Seperti diharamkannya meminum khamr adalah untuk menjaga akal manusia dari kerusakan.

Hanya saja dalam kasus-kasus tertentu banyak kemaslahatan yang tidak tercover dalam hukum. Padahal sejatinya kemaslahatan manusia adalah tujuan utama bagi dibentuknya hukum. Di samping itu kemaslahatan manusia sangat banyak dan selalu terbaharui seiring dengan terbaharuinya keadaan manusia. Hal itu pun terus berkembang dengan perbedaan lingkungan. Sehingga konsekwensinya banyak kemaslahatan yang menjadi tuntutan keadaan manusia terutama setelah terputusnya wahyu.

Atas dasar inilah dibentuklah suatu hukum demi terwujudnya maslahat itu dengan berdasarkan ijtihad. Contoh yang banyak dijumpai adalah kebijakan hukum yang dilakukan pada masa sahabat. Seperti halnya khalifah Umar yang membuat penjara, menjatuhkan thalaq tiga dengan satu kalimat, menghentikan pelaksanaan hukum potong tangan pada masa peceklik. Termasuk juga kebijakan khalifah utsman yang mengumpulkan umat Islam dalam satu mushaf al-Qur'an lalu menyebarkannya dan membakar mushaf lainnya. Semua ini adalah hukum yang di dalamnya terkandung kemaslahatan. Meski dalam dalam pengkajiannya tidak terlepas dari pro dan kontra.

Kebolehan menggunakan al-Maslahah al-Mursalah tidak boleh terlepas dari kehati-hatian. Sehingga al-Maslahah al-Mursalah tidak

38 Abdul Wahhab Khalaf, Ilmu Ushul al-Figh, Hal. 84

39 Tentang tujuan diturunkannya syariat dari syari' kepada manusia akan dibahas dalam pembahasan Kaidah-kaidah ushuliyah aspek pembebanan Syariat (القواعد الأصولية التشريعية). 
menjadi akses bagi kepentingan dan hawa nafsu manusia. Oleh karenanya al-Maslahah al-Mursalah yang dijadikan pijakan hukum harus memenuhi tiga kriteria:

1. Maslahat yang dijadikan pertimbangan adalah maslahat yang nyata dan sesungguhnya, bukan maslahat yang masih menjadi praduga. Maksudnya adalah dalam maslahat tersebut benar-benar diyakini bahwa pembentukan hukum bagi peristiwa tertentu mampu menarik manfaat dan menolak bahaya. Jika semua itu hanya semata-mata masih praduga maka hal itu tidak bisa disebut sebagai maslahat yang sebenarnya.

2. Maslahat yang dijadikan pertimbangan adalah maslahat umum bukan maslahat individual. Dengan ini harus diyakini bahwa pembentukan hukum bagi peristiwa tertentu mampu menarik manfaat bagi mayoritas manusia, atau mampu menolak bahaya bagi sebagian besar mereka. Pembentukan hukum ini bukan justru untuk kemaslahatan pribadi atau kelompok minoritas.

3. Pembentukan Hukum demi kemaslahatan ini tidak boleh bertentangan dengan hukum atau prinsip hukum yang telah ditetapkan oleh nash atau ijma'. Dengan ini maka tidak benar bila membentuk hukum yang menuntut kesamaan antara anak lakilaki dan perempuan dalam perolehan bagian harta waris. Sebab hal itu bertentangan dengan al-Qur'an sehingga maslahat semacam itu disebut dengan maslahat mulghah (tidak benar).

Dalam kajian ini lebih ditekankan keseimbangan dan kehatihatian. Sebab membuka peluang al-Maslahah al-Mursalah tanpa batas sama saja melakukan justifikasi terhadap kepentingan manusia. Namun bila peluang tersebut ditutup serapat mungkin, maka akan membuat syariat akan kehilangan ruhnya untuk mewujudkan kemaslahatan manusia serta membuat mereka menjadi lebih baik. 40

C. Tujuan Umum Pembentukan Syari'at

Kajian tentang Tujuan umum pembentukan syari'at (قاصـ merupakan salah satu bagian dari Kaidah-Kaidah Ushuliyah dari sudut pandang Pembentukan Syariat sebagai sesuatu yang bekaitan dengan kemaslahatan manusia (القو اعد الأصولية التشريعية).

${ }^{40}$ Abdul Wahhab Khalaf, Ilmu Ushul al-Figh, hal. 84-88 
Setelah dilakukan penelitian tentang hukum-hukum syariat maka para ulama ushul fiqh menyusun kaidah-kaidah ini. Nash-nash syar'i membentuk prinsip-prinsip dalam menetapkan hukum-hukum syariat secara umum serta dasar-dasarnya secara keseluruhan.

Sebagaimana prinsip-prinsip ini wajib dijaga (dijadikan pertimbangan) dalam melakukan penggalian hukum (إستنباط الأحكام) dari nash-nash yang ada, maka wajib pula dipelihara dalam melakukan penggalian hukum tentang sesuatu yang tidak ada penegasan dari syari'. Hal ini supaya pembentukan syariat mampu merealisasikan maksud-maksud diturunkannya guna mengantar kepada upaya mewujudkan kemaslahatan manusia dan keadilan di antara mereka.

Tujuan umum bagi syari' ${ }^{41}$ dalam membentuk hukum syariat adalah mewujudkan kemaslahatan bagi manusia dengan menjamin kebutuhan primer dan memenuhi kebutuhan sekunder dan tersier mereka. Setiap hukum syariat tidaklah memiliki maksud apa-apa kecuali salah satu dari tiga hal tersebut yang merupakan komposisi maslahat bagi manusia.

Urutan pertama adalah kebutuhan primer (الضروريّات). Kedua adalah kebutuhan skunder (الحاجيات) dan ketiga adalah kebutuhan tersier (التحسينيات).42 Perkara tersier tidak bisa upayakan bila dalam mengupayakannya bisa merusak terhadap perkara skunder. Begitu pun, perkara skunder atau tersier tidak dapat diwujudkan bila dalam mewujudkannya bisa merusak bagi perkara primer. ${ }^{43}$ Selain itu pemebnetukan syariat juga dimaksudkan untuk mewujudkan kemaslahatan bagi manusia dengan menarik manfaat bagi manusia dan menolak bahaya (الضرر) dari mereka.

1. Kebutuhan Primer (الضروريّات)

41 Syari' adalah dzat yang membentuk dan menurukan kepada manusia. Dalam kajian fiqh, syari' ada dua. Yaitu : Syari' hakiki yakni Allah SWT dan Syari' Majazi yakni Rasul SAW

42 Dalam hal ini penggunnaan kata kebutuhan primer, sekunder dan tersier hanya demi memudahkan dalam memahami, sebab redaksi kata dimaksud sudah maklum secara umum. Sedangkan redaksi asli ketiga kebutuhan ini adalah الأمور الضروريات, الأمور الحاجيات و الأمور التحسينيات

${ }^{43}$ Abdul Wahhab Khalaf, Ilmu Ushul al-Fiqh, Hal. 197 
Kebutuhan primer adalah perkara yang menjadi pijakan bagi hidup manusia dan harus ada demi tegaknya kemaslahatan bagi mereka. Yang sekiranya jika perkara ini tidak ada maka kehidupan manusia menjadi kacau dan menimbulkan kekacauan di mana-mana. Perkara primer itu kembali kepada pemeliharaan lima hal, yakni agama, jiwa, akal, kehormatan dan harta. Dengan ini maka menjaga salah satu dari yang lima tersebut adalah kebutuhan primer bagi manusia. ${ }^{44}$ Konsep ini juga dikenal dengan Maqashid asy-Syariah.

a. Menjaga agama (حفظ الدين) adalah dengan menjaga keseluruhan akidah (keyakinan tauhid), ibadah-ibadah, hukum dan perundang-undangan yang telah Allah syariatkan untuk mengatur hubungan antara manusia dengan tuhan, antara manusia dengan sesame. Untuk mewujudkannya Allah telah mensyariatkan agama Islam guna mewujudkan serta menegakkan agama dengan mewajibkan iman dan melaksanakan lima rukun Islam. Kelima rukun itu adalah : 1) Bersaksi bahwa sesungguhnya tiada Tuhan selain Allah dan sesungguhnya Muhammad adalah utusan Allah, 2) Mendirikan shalat, 3) Menunaikan zakat, 4) Puasa pada bulan ramadlan, dan 5) Haji.

Selain itu juga termasuk perkara agama yang wajib dijaga adalah akidah-akidah secara total, prinsip-prinsip ibadah, menegakkan agama serta menetapkannya dalam hati dengan mengikuti hukum-hukum yang dan mewajibkan dakwah sekaligus menjamin dakwah juga da'i tersebut dari gangguan.

b. Menjaga jiwa (حفظ النفس). Islam mensyariatkan untuk mewujudkannya dengan syariat nikah untuk menghasilkan keturunan dan mempertahankan spesies manusia secara utuh. Untuk menjaga jiwa Allah telah mensyariatkan dengan 1) mewajibkan mengkonsumsi makanan yang mampu membuatnya tegak, minum, pakaian, dan tempat tinggal, 2) mewajibkan qishash, diyat, kaffarat bagi orang yang melakukan perkara pidana dengan sengaja, 3) mengharamkan menjerumuskan diri ke dalam kehancuran serta 4) mewajibkan menolak bahaya dari kemusnahan.

44 Dalam penetapannya para ulama memiliki pendapat yang berbeda-beda. Lihat: Jamaluddin 'Athiyyah, Nahwa Taf'il Maqashid al-Syariah, Dar al-Fikr, Damaskus, 2001, Hal. 28-31. 
c. Menjaga akal (حفظ العقل) adalah dengan 1) Syariat diharamkannya meminum khamr dan setiap sesuatu yang memabukkan, 2) memberlakukan sanksi bagi orang yang mengkonsumsinya.

d. Menjaga kehormatan (حفظ العرض). Untuk menjaganya Allah telah mensyariatkan had bagi orang yang melakukan zina, baik lakilaki maupun perempuan dan had bagi orang menuduh zina.

e. Menjaga harta (حفظ المال). Dalam hal ini Islam telah memberikan syariat untuk mencapai dan mengusahakannya yakni dengan 1) mewajibkan berusaha mencari rezeki, 2) membolehkan muamalat (transaksi), barter, perniagaan dan bagi hasil, 3) mengharamkan tidak pencurian, 4) memberlakukan had bagi orang yang mencuri baik laki-laki maupun perempuan, 5) mengharamkan tindak penipuan $^{45}$, khianat ${ }^{46}$, dan memakan harta manusia secara batil, 6) merusak harta orang lain dan mewajibkan mengganti bagi orang yang melakukannya, 7) melarang pengelolaan harta bagi orang yang lemah akal dan sering lalai, 8) mewajibkan menolak bahaya bagi harta dan mengharamkan riba.

Terhadap lima prinsip kebutuhan primer ini Islam sangat serius menjaganya hingga membolehkan melakukan perkara-perkara yang dilarang pada saat genting atau darurat.

2. Kebutuhan Skunder (الحاجيات)

Kebutuhan skunder adalah perkara yang dibutuhkan manusia untuk kemudahan dan keluasan, memikul beban serta beratnya hidup. Yang sekiranya meski perkara ini tidak ada namun kehidupan manusia tidak sampai menjadi kacau dan dan tidak menimbulkan kerusuhan di mana-mana (sebagaimana ketiadaan perkara primer).

Perkara-perkara skunder ini kembali kepada upaya untuk menghilangkan kesulitan dari manusia serta meringankannya supaya mereka mampu memikul beban syariat, serta menjadi mudah aksesakses untuk menjalin kerjasama, hubungan timbal balik dan jalan kehidupan.

${ }^{45}$ Dengan menyembunyikan cacat barang pada yang dijual dan lain sebagainya.

${ }^{46}$ Yang juga bersifat menipu namun lebih cenderung ke akad atau transaksi. 
Dalam perkara skunder ini Islam telah mensyariatkan dalam berbagai bab atau dimensi yakni : ibadah, mumalah, sanksi-sanksi, dan menghilangkan kesempitan serta memudahkan manusia.

Dalam ibadah Allah telah mensyariatkan Rukhshah (dispensasi) untuk meringankan orang-orang yang mukallaf bila dalam melakukan ibadah terdapat kesulitan. Karenanya Allah 1) membolehkan untuk tidak berpuasa (الفطر) bagi orang yang tengah berpergian atau sakit pada bulan ramadlan, 2) membolehkan untuk mengqashar shalat yang terdiri dari empat rakaat, 3) membolehkan shalat dengan duduk bagi orang yang tidak mampu shalat berdiri 4) membolehkan tayammum bagi orang yang tidak menjumpai air untuk berwudlu', 5) membolehkan shalat diatas perahu walaupun arahnya bergeser dari kiblat, dan lain-lain yang merupakan rukhshah lainnya yang disyariatkan untuk menghilangkan kesulitan manusia dalam melakukan ibadah.

Dalam muamalah Allah telah banyak mensyariatkan dalam berbagai akad dan penggunaan barang yang menjadi tuntutan kebutuhan manusia, seperti 1) jual beli, sewa menyewa, perkongsian, dan bagi hasil, 2) memberikan keringanan terhadap akad (yang kebolehannya) tidak tertutup rapat menurut Qiyas, 3) aturan-aturan umum dalam berbagai akad, seperti akad salam (memesan barang), dan lainnya yang sejalan dengan kebiasaan manusia, 4) mensyariatkan thalaq untuk melepaskan diri dari ikatan perkawinan saat dibutuhkan secara terdesak, 5) membolehkan daging binatang buruan, bangkai hewan laut dan makanan-makanan yang baik dari karunia-Nya, 6) menjadikan kebutuhan skunder sama dengan kebutuhan primer dalam hal kebolehan melakukan perkara yang dilarang oleh agama.

Dalam hal sanksi Allah telah menjadikan 1) diyat bagi orang yang dikenakan diyat untuk meringankan bagi pihak orang yang terbunuh secara salah (tidak disengaja), 2) menolak had dalam keadaan syubhat ${ }^{47}$, 3) memberikan hak memaafkan dari qishash si pembunuh bagi wali orang yang terbunuh.

3. Kebutuhan tersier (التحسينيات)

47 Dalam keadaan si pembunuh tidak diketahui secara jelas karena keterbatasan bukti, saksi dan lain sebagainya. 
Kebutuhan tersier adalah sesuatu yang dituntut oleh oleh prestise, adab kesopanan dan proses dengan metode yang paling ideal. Yang sekiranya meski perkara ini tidak ada namun kehidupan manusia tidak sampai menjadi kacau dan tidak menimbulkan kerusuhan di mana-mana (sebagaimana ketiadaan perkara primer) serta tidak menimbulkan kesempitan bagi manusia (sebagaimana ketiadaan perkara skunder).

Namun kehidupan manusia meminta ${ }^{48}$ untuk menguasai akal yang unggul dan fitrah normal manusia. Perkara tersier kembali kepada akhlak yang terpuji, kebiasaan yang baik, dan setiap sesuatu berupa perbuatan manusia yang menggunakan metode yang paling ideal.

Dalam ibadah, Allah telah mensyariatkan 1) untuk mensucikan badan, pakaian, tempat, menuntup aurat dan menghidar dari benda-benda najis, 2) menyucikan diri dari kencing (kotoran), 3) mensunnahkan untuk memakai pakaian yang indah di setiap (memasuki) masjid, 4) memerintahkan untuk melakukan perkara sunnah berupa shadaqah, shalat, dan puasa, dan setiap ibadah yang rukun-rukun serta syarat-syaratnya disyariatkan sebagai bagian dari etika bagi ibadah itu. Hal itu semua untuk membiasakan manusia dengan kebiasaan yang paling baik.

Dalam hal Muamalah Allah telah 1) mengharamkan penipuan, penyembunyian cacat (pada barang yang ditransaksikan), israf (berlebihan dalam menggunakan harta) dan kikir (terlalu hemat dalam menggunakan harta), 2) mengharamkan bekerja sama dalam setiap perkara najis dan membahayakan, 3) melarang penjualan seeorang terhadap penjualan saudaranya sesama muslim (monopoli), jual beli dengan mencegat di tengah jalan ${ }^{49}$, penentuan harga, ${ }^{50}$ dan

48 Dalam hal ini digunakan kata "meminta" yang terkesan tidak terlalu mendesak. Berbeda dengan kebutuhan skunder apalagi primer yang menggunakan "menuntut". Hal itu disebabkan kebutuhan skunder dan primer lebih mendesak daripada kebutuhan tersier.

49 Jual beli dengan menarik seluruh harta perniagaan dengan cara mencegat si penjual dalam perjalanan menuju pasar. Jual beli semacam ini tidak boleh, sebab ada potensi dari si pembeli untuk membeli dengan harga murah. Yakni harga di bawah harga pasaran. Si penjual akan mudah dikelabui sebab dirinya belum sempat memasuki pasar hingga ia tidak 
lain-lain yang mampu membuat transaksi antar perorangan menjadi metode yang paling ideal.

Dalam sanksi-sanksi, Allah 1) mengharamkan untuk membunuh para pendeta, anak-anak dan wanita, 2) melarang untuk melanggar perjanjian, 3) melarang membakar mayat atau orang yang masih hidup.

D. Kondisi Umum Pamekasan

Pamekasan secara geografis dapat dijelaskan secara singkat sebagai berikut :

1. Letak Daerah : 113019' - 113058' BT | 6051' - 7031' LS

2. Batas Daerah :
a. Utara : Laut Jawa
b. Selatan : Selat Madura
c. Barat : Kabupaten Sampang
d. Timur : Kabupaten Sumenep

3. Ketinggian Dari Permukaan Laut

a. Tertinggi : $350 \mathrm{~m}$

b. Terendah: $6 \mathrm{~m}$

4. DAU

5. Luas

: Rp. 702.610.217.000.-(2013)[1]

6. Populasi :

: $732,85 \mathrm{~km} 2$

a. Total

:18.662 jiwa

7. Demografi

b. Kepadatan :1.117,09 jiwa/km2

a. Kode area telepon :0324

8. Pembagian administratif

a. Kelurahan :178 desa \& 11 kelurahan

b. Kecamatan :13

1) Kec. Waru

2) Kec. Pakong

3) Kec.Batu Marmar

mengetahui harga pasaran. (Lihat: Muhammad ibn Isma'il, Subul al-Salam, al-Maktabah al-Syamilah, Juz 4, Hal. 114)

${ }^{50}$ Penentuan harga di sini yang sekiranya merugikan pedagang atau pembeli. Namun dalam konteks modern hal ini menjadi bagian kebijakan dari hakim (pemerintah), terutama terhadap barang yang menyangkut hajat orang banyak. 
4) Kec.Galis

5) Kec.Kadur

6) Kec.Larangan

7) Kec.Pademawu

8) Kec.Palengaan

9) Kec.Pamekasan

10) Kec.Pasean

11) Kec.Pegantenan

12) Kec.Proppo

13) Kec.Tlanakan 51

Pamekasan, selain dikenal Gerbang Salam dan Kota Batik. Selain itu juga dinobatkan sebagai Kabupaten Pendidikan karena banyaknya lembaga pendidikan mulai dari Tingkat Taman KanakKanak sampai Perguruan Tinggi. Predikat Kabupaten Pamekasan sudah diresmikan oleh Mendikbud Moh. Nuh pada akhir tahun 2012 lalu, sejak saat itulah Kabupaten pamekasan secara resmi mendeklarasikan diri menjadi kabupaten Pendidikan. ${ }^{52}$

Predikat kabupaten Pendidikan diraih atas keberhasilan kabupaten pamekasan dalam menggalakkan pendidikan, sehingga dari tahun ke tahun terus bertabur prestasi baik dari tingkat lokal, regional, hingga internasional. ${ }^{53}$

\section{E. Nikah Siri di Pamekasan}

Pengertian dari Nikah siri adalah nikah rahasia sembunyisembuyi. Disebut demikian karena tidak dilaporkan ke kantor urusan agama atau KUA bagi muslim atau kantor catatan sipil bagi non muslim. Biasanya nikah siri dilakukan karena dua pihak belum siap melakukannya secara resmi, namun di pihak lain agar tidak terjadi

51 Tim Penyusun, Pamekasan dalam Sejarah, Karunia Offset, 2006, hal. $14-30$

52 Dilansir oleh $\underline{\text { https://id.wikipedia.org/wiki/Kabupaten_Pamekasan }}$ pada tanggal 30 Oktober 2016.

${ }^{53}$ http:// www.pamekasankab.go.id/ 
perbuatan yang tidak diinginkan atau terjerumus kepada zina dan lainnya. ${ }^{54}$

Nikah siri adalah nikah yang tidak bisa menghadirkan wali dan tidak mencatatkan pernikahannya ke KUA. Disebutkan bahwa wanita yang telah dewasa dan berakal maka diperbolehkan memilih sendiri calon suami baginya. Dia tidak hanya bergantung pada walinya saja.

Patut disayangkan praktik nikah siri di Pamekasan masih marak terjadi di Pamekasan. Sebagai akibat pernikahannya tidak dicatat di KUA, seorang anak, istri, atau suami gagal mendapatkan harta waris. Karena mereka tidak memiliki bukti otentik pernikahan berupa buku nikah. Hal ini merupakan efek negatif nikah siri yang seringkali terabaikan oleh masyarakat. ${ }^{55}$

Sebenarnya praktik semacam ini tetap merugikan masyarakat. Sebab bila mereka selama ini menghindari nikah yang sah melalui KUA dengan alasan biaya mahal, maka sesungguhnya mereka tetap membayar mahal ketika mereka melakukan istbat nikah di pengadilan agama (PA) setempat dengan biaya yang jauh lebih mahal. Hal ini terjadi sebab :

1. Biaya mahal itu tidak hanya secara administrasi perkara di pengadilan agama (PA) tetapi juga biaya transportasi, menguras tenaga dan waktu. Mengingat sidang di PA masih melalui serangkaian pembuktian dan pemenuhan persyaratan. Adapun syarat untuk melakukan itsbat nikah adalah sebagai berikut:

a. Surat Permohonan;

b. foto copy KTP;

c. Surat Keterangan dari Desa/Kelurahan yang menyatakan bahwa Pemohon pernah menikah;

d. Menyerahkan Surat Keterangan dari KUA bahwa pernikahan Pemohon tidak/register nikah tahun pernikahan Pemohon tidak ditemukan;

e. Membayar biaya perkara sesuai radius.

f. Lain-lain yang akan ditentukan Hakim dalam persidangan.

\footnotetext{
${ }^{54}$ Amir Syarifuddin, Hukum Nikah Islam di Indonesia: Antara Fikih Munakahat dan Undang-Undang Nikah, hal. 70

55 Realita ini juga pernah diungkap dalam http://radarmadura.co.id/2015/12/prihatin-nikah-siri-marak/
} 
2. Itsbat nikah pada akhirnya akan ditempuh untuk pemenuhan persyaratan ketika mengajukan pembuatan akta lahir anak atau untuk kepentingan mereka (pasutri nikah siri) seperti pembuatan paspor. Mengingat budaya kerja masyarakat Madura yang lebih memilih merantau ke luar daerah bahkan ke luar negeri. Jika saja mereka melakukan pernikahan secara sah di KUA, masalahmasalah tersebut tidak akan dijumpai di kemudian hari.

Untuk mengurangi angka pernikahan di bawah tangan tersebut maka pemerintah kabupaten Pamekasan menyelenggarakan nikah massal. Nikah massal ini tidak hanya diikuti oleh pasangan suami istri (pasutri) muda, tapi juga pasutri yang sudah menikah sejak lama, namun belum mengantongi surat nikah. Secara total nikah massal ini diikuti oleh 219 pasangan. ${ }^{56}$ Jumlah istbat nikah dilakukan di kabupaten Pamekasan berjumlah 26 orang. Itu belum termasuk mereka yang terlibat dalam nikah massal. ${ }^{57}$

\section{Alasan Melakukan Nikah Siri}

Dari beberapa wawancara terbuka dengan pelaku nikah siri dapat disimpulkan bahwa alasan mereka beragam. Lebih jelasnya sebagai berikut:

a) Biaya Nikah Mahal

Ini merupakan hasil wawancara kami dengan bapak Sa'i (Tebul Barat Kec. Pegantenan). Adapun jalannya wawancara sebagai berikut :

Peneliti: "Assalamu alaikum bapak"

Responden : "Wa'alaikumussalam"

P: "Sejak kapan bapak melakukan nikah siri"

R: "Sejak 2002"

P : "Berapa putra bapak sekarang?"

$\mathrm{R}$ : "Dua, satu laki-laki, satu perempuan"

P: "Mengapa bapak melakukan nikah siri?"

${ }^{56}$ Kabar ini sempat menjadi pemberitaan nasional, bahkan sempat dilansir oleh http://news.detik.com/berita-jawa-timur/d-3327727/219pasangan-asal-pamekasan-ikut-nikah-massal-gratis pada Senin 24 Oktober 2016 pada jam 11:02 WIB.

57 Sebagaimana pada keterangan dari bpk. Muhammad Nasir, pegawai Kantor Urusan Agama (KUA) Pamekasan. 
R : "Begini dik. Menikah di KUA itu mahal. Saya ini kerjanya sebagai petani, kadang buruh tani. Sampeyan sudah tahu kan berapa penghasilan saya. Sehingga saya tidak mampu untuk nikah melalui KUA. Makanya saya nikah ke kiai saja."

P : "Apakah bapak tahu bahwa akad nikah bila dilaksanakan di KUA (Kantor Urusan Agama) sekarang tidak dipungut biaya, alias gratis" R: "Masak dik? Nggak tahu saya"

P : "Iya bapak. Ini diatur dalam Peraturan pemerintah no. 19 tahun 2015. Nikah bila akadnya dilakukan di KUA tidak dikenakan biaya.

$\mathrm{R}$ : "Ya kalo saya sudah terlanjur begini gimana. Wong saya sudah terlanjur punya anak seperti ini. Ya mungkin kelak anak saya semoga bisa nikah secara resmi (di KUA)"

P : "Baik bapak terima kasih atas jawabannya"

$\mathrm{R}$ : "Sama-sama"

P : "Assalamu alaikum"

$\mathrm{R}$ : "Wa'alaikumussalam"

Kesimpulan ini juga disampaikan oleh bapak Arip (Desa Bujur Barat kec. Batumarmar), Bapak Busamin (Desa Pangtonggal kec. Pegantenan) dan Bapak Sukkur (Desa Ambender Kec. Pegantenan).

b) Administrasi Rumit

Ini merupakan hasil wawancara kami dengan bapak Damar (warga desa Ambender Kec. Pegantenan). Adapun jalannya wawancara sebagai berikut:

Peneliti: "Assalamu alaikum bapak"

Responden : "Wa'alaikumussalam"

P: "Sejak kapan bapak melakukan nikah siri"

R: "Sejak 2007"

P : "Berapa anak bapak sekarang?"

$\mathrm{R}$ : "satu dik. laki-laki"

P : "Mengapa bapak melakukan nikah siri?"

$\mathrm{R}$ : "Saya melakukan nikah siri ini karena KTP saya itu mati (sudah habis masa berlakunya, red) katanya untuk mengurus syarat nikah di KUA itu harus KTP yang masih hidup (masa berlakunya masih ada, red.) makanaya saya masih harus mengurus KTP dulu baru ngurus syarat nikah di KUA. Saya tanya lagi, ternyata masih harus menyetorkan ini itu"

P : "ini itu, maksudnya apa pak" 
R : "Ya itulah dik. Fotocopy KK (kartu keluarga, red) ijazah terakhir dan lain-lain lah. Ijazah saya kan gak tau dimana"

P : "Apakah bapak tahu bahwa akad nikah bila dilaksanakan di KUA (Kantor Urusan Agama) sekarang tidak dipungut biaya, alias gratis" R: "Nggak tahu saya. Cuma dengar-dengar begitu"

$\mathrm{P}$ : "Terima kasih atas jawabannya pak"

R: "Ya. Sama-sama dik"

P : "Assalamu alaikum"

$\mathrm{R}$ : "Wa'alaikumussalam"

Hal ini juga disampaikan oleh bapak Ramli (Desa Batu Bintang kec. Batumarmar), Samha (Desa Pasanggar kec. Pegantenan) dan bapak Mukhlis (Desa Samiran Kec. Proppo).

c) Anggapan nikah siri sudah "cukup" secara hukum.

Ini merupakan hasil wawancara kami dengan bapak Supraji (desa Blaban kec. Batumarmar). Adapun jalannya wawancara sebagai berikut :

Peneliti: "Assalamu alaikum bapak"

Responden : "Wa'alaikumussalam"

P: "Sejak kapan bapak melakukan nikah siri"

R: "Sejak 1995 nak"

P : "Berapa anak bapak sekarang?"

R : "Dua nak. laki-laki semua"

P : "Mengapa bapak melakukan nikah siri?"

R : "gak tau dik. katanya orang-orang sini, nikah sama kiai sudah cukup. Makanya saya nikah ke kiai saja"

P : "Apa bapak tau bahwa itu tidak sah menurut negara, karena tidak tercatat di KUA"

$\mathrm{R}$ : "Itu kan barusan-barusan saja. Dulu (nikah) ke kiai sudah cukup"

$\mathrm{P}:$ "O begitu ya pak"

$\mathrm{R}$ : "Iya nak"

P : "Apa kepala desa tahu tentang ini. Bahwa bapak hanya nikah ke kiai saja dan tidak tercatat di KUA"

R: "Iya nak. Beliau tahu"

P : "Apakah bapak tahu bahwa akad nikah bila dilaksanakan di KUA

(Kantor Urusan Agama) sekarang tidak dipungut biaya, alias gratis"

$\mathrm{R}$ : "Saya nggak tahu. Mana pemerintah gak ngasi tahu"

$\mathrm{P}$ : "Terima kasih atas jawabannya pak" 
$\mathrm{R}$ : "Ya. Sama-sama nak"

P : "Assalamualaikum"

$\mathrm{R}$ : "Wa'alaikumussalam"58

Alasan serupa juga disampaikan oleh bapak Mura'i (Desa Batu Bintang kec. Batumarmar), bapak suli (Desa Pasanggar kec. Pegantenan) dan Hamid (Desa pangorayan Kec. proppo).

\section{Akibat Nikah Siri}

Selain pembahasan di atas perlu kami sampaikan tentang dampak positif dan negatif prilaku nikah siri:

1. Efek Positif :

a. Mengurangi kumpul kebo, seks bebas, serta berkembangnya penyakit penyakit kelamin dan lainnya.

b. Mengurangi Tanggung jawab seorang wanita yang menjadi beban keluarganya.

c. Mengurangi diskriminasi sosial dan tekanan psikologis terhadap perempuan-perempuan yang dianggap 'tidak laku'.

2. Dampak Negatif :

a. Menciptakan anggapan bahwa perselingkuhan adalah hal biasa.

b. Menimbulkan banyak perilaku Poligami secara rahasia berikutnya.

c. Tidak adanya kejelasan status hukum isteri dan anak dan status sosial masyarakat sekitar.

d. Rentan penelantaran nafkah terhadap anak dan istri karena posisi mereka yang tidak kuat secara hukum.

e. Pelecehan seksual terhadap kaum hawa karena dianggap sebagai pelampiasan nafsu sesaat bagi kaum Laki-laki.

f. Terhalangnya si anak hasil nikah siri mendapatkan akta kelahiran.

Maka dengan demikian jika dilihat dari fakta yang ada, semakin terlihat bahwasanya nikah siri lebih banyak membawa

58 Wawancara ini dilakukan pada kamis, 27 Oktober 2016 dengan menemui satu persatu informan secara manual, setelah sebelumnya membuat janji untuk bertemu di satu tempat atau di tempat responden berada. Karena beberapa responden tidak bersedia diwawancara secara terbuka. 
dampak negatif di banding positifnya. Yang paling pengting adalah status hukum istri sehingga tidak dapat menuntut suami untuk memberikan nafkah baik lahir maupun batin, anak tidak bisa sekolah karena tidak punya akta kelahiran. Sedangkan, semua sekolah saat ini mensyaratkan akta kelahiran dan dalam hal pewarisan, pernikahan siri maupun isteri yang dinikahi secara siri, akan sulit untuk menuntut haknya, karena tidak ada bukti yang menunjang. ${ }^{59}$

F. Analisis Terhadap Argumen Masyarakat Yang Melakukan Nikah Siri Di Kabupaten Pamekasan

Dalam sudut pandang hukum positif, sesuai dengan peraturan perundang-undangan tentang Perkawinan menurut Ps. 2 ayat (1) UU. No. 1/1974 tentang Perkawinan adalah sah apabila dilakukan menurut hukum masing-masing agamanya dan kepercayaannya itu, yang dipertegas dalam Penjelasan Pasal 2 UU. No. 1/1974 tentang Perkawinan tersebut, yakni bahwa "dengan perumusan pada Pasal 2 ayat (1) ini, tidak ada perkawinan diluar hukum masing-masing agamanya dan kepercayaannya itu, sesuai dengan Undang-Undang Dasar 1945.

Yang dimaksud dengan hukum masing-masing agamanya dan kepercayaannya itu termasuk ketentuan perundang-undangan yang berlaku bagi golongan agamanya dan kepercayaannya itu sepanjang tidak bertentangan atau tidak ditentukan lain dalam Undang-Undang ini". Ini berarti bahwa jika suatu perkawinan telah memenuhi syarat dan rukun nikah atau ijab kabul telah dilaksanakan atau (bagi non muslim) pendeta/pastur/biksu telah melaksanakan pemberkatan atau ritual lainnya, maka perkawinan tersebut adalah sah menurut anggapan masyarakat.

Karena dianggap sah, maka kemudian dijumpai banyak perkawinan yang tidak dicatatkan. Hal ini disebabkan oleh beberapa hal, antara lain :

1. ketidaktahuan masyarakat mengenai hukum perkawinan Indonesia,

2. sosialisasi pencatatan perkawinan yang kurang dari Pemerintah,

${ }^{59}$ Hadi Nurhaedi, Nikah di bawah Tangan (Praktek Mahasiswa Nikah Siri Mahasiswa Yogyakarta), hal. 89 
3. persyaratan dan prosedur pencatatan perkawinan yang dianggap rumit dan berbelit-belit, serta

4. mahalnya biaya pencatatan perkawinan, baik resmi maupun tidak resmi, (ataupun untuk menghilangkan jejak dan bebas dari tuntutan hukum dan hukuman administrasi dari atasan, terutama untuk perkawinan kedua dan seterusnya, bagi Pegawai Negeri Sipil dan Angkatan Bersenjata Republik Indonesia).

Perkawinan yang tidak dicatatkan ini dikenal dengan istilah perkawinan bawah tangan atau nikah siri. Pasal 2 ayat (2) UU. No. 1/1974 tentang Perkawinan, menentukan: "tiap-tiap perkawinan dicatat menurut perundang-undangan yang berlaku", namun di dalam penjelasan tidak dijelaskan lebih lanjut tentang pendaftaran ini. Harus diakui ketentuan yang mengatur tentang sah dan pencatatan perkawinan kurang jelas, sehingga dalam praktik sering sekali menimbulkan berbagai interpretasi, yang menyebabkan kepastian hukum menjadi taruhannya.

Hal ini merupakan fenomena sosial - hukum yang dijumpai di kalangan masyarakat Kabupaten Pamekasan dan merupakan salah satu masalah serius yang sampai saat ini masih kerap terjadi dalam masyarakat di Kabupaten Pamekasan. Hal tersebut bukan hanya dijumpai pada kalangan masyarakat di Kabupaten Pamekasan bergolongan ekonomi menengah ke bawah saja, melainkan juga dijumpai pada masyarakat di Kabupaten Pamekasan bergolongan ekonomi menengah ke atas. Sehingga tingkat ekonomi bukan merupakan faktor mutlak yang mempengaruhi tidak dicatatnya perkawinan dalam masyarakat di Kabupaten Pamekasan.

Faktor utama yang menyebabkan perkawinan tidak dicatatkan pada masyarakat di Kabupaten Pamekasan lebih cenderung disebabkan oleh ketidaktahuan, keawaman, dan cara berpikir masyarakat di Kabupaten Pamekasan terhadap pentingnya pencatatan perkawinan, fungsi dan akibat-akibat hukum yang timbul dikemudian hari. Masyarakat di Kabupaten Pamekasan yang memegang teguh adat istiadat berpendapat bahwa suatu perkawinan adalah sah dan telah diakui oleh kedua belah pihak keluarga suami/isteri apabila perkawinan tersebut telah dilaksanakan menurut adat di Kabupaten Pamekasan dan menjalani serangkaian ritual keagamaan, maka perkawinan tersebut telah sah, tidak 
mempedulikan dicatat atau tidak perkawinan tersebut menurut ketentuan peraturan perundang-undangan yang berlaku.

Bagi keluarga mempelai yang mampu akan mengadakan suatu acara resepsi pernikahan dengan mengundang segenap keluarga kedua belah pihak mempelai suami/isteri, tetangga dan para sahabat. Acara resepsi pernikahan tersebut secara tidak langsung juga berfungsi sebagai pemberitahuan atau pengumuman kepada khalayak ramai bahwa telah terikatnya seorang laki-laki sebagai suami dan seorang wanita sebagai isteri dalam suatu ikatan perkawinan. Namun perlu diingat bahwa acara resepsi pernikahan ini bukan merupakan suatu acara yang mutlak harus dilaksanakan, melainkan tergantung kepada tingkat kemampuan ekonomi suatu keluarga yang melaksanakan perkawinan tersebut.

Hal itu dapat dilihat dari adanya pelaksanaan pesta pernikah (walimatu urus) dengan melakukan resepsi biasanya keluarga, kerabat dan sahabat kedua mempelai yang di undangnya terutama tetangga terdekat setempat, yang memiliki tujuan yang sama yakni memberitahukan kepada khalayak ramai bahwa telah dilaksanakannya pernikahan bersangkutan dan telah terikatnya dalam perkawinan pasangan suami/isteri tersebut. Adat dan pandangan inilah yang dipegang teguh oleh masyarakat di Kabupaten Pamekasan Indonesia hingga saat ini. Keengganan dan ketidaktahuan hukum masyarakat di Kabupaten Pamekasan atas pencatatan perkawinan tanpa disadari akan membawa kesulitan dan akibat hukum yang tidak baik dikemudian hari.

G. Upaya Pemerintah Kabupaten Pamekasan dalam Meminimalisir Nikah Siri

Pemerintah daerah kabupaten pamekasan menggandeng perangkat institusi kantor Urusan Agama setelah ditinjau dari berbagai aspek dan kepentingan, baik kepentingan individu, kepentingan keluarga dan kelompok masyarakat, kepentingan agama dan hukum negara, serta sebagai fenomena sosial yang terjadi di masyarakat. Pengkajian lembaga perkawinan tidak hanya dapat dikritisi dari aspek hukum normatif saja, namun yang lebih penting 
dari hukum negara setelah jumlah angka perkawinan tidak terdaftar (nikah siri) setiap tahun terus menerus terjadi.60

Perkara itsbat nikah jauh sedikit dibandingkan dengan jumlah perkara cerai, baik karena permohonan, maupun cerai gugat sehingga disni masih perlu penyadaran pentingnya administrasi dalam pernikahan. Langkah pemerintah daerah untuk menghindari terjadinya permohonan itsbath nikah ke Pengadilan Agama bagi pasangan yang tidak mempunyai akta nikah dengan melakukan program nikah massal yang dibuat oleh pemerintah daerah yang bekerjasama dengan pihak ketiga sebagai langkah mengatasi problematika tingginya jumlah perkawinan yang tidak terdaftar tetapi program ini masih belum memberikan kesadaran hukum terhadap masyarakat di kabupaten Pamekasan.

Program nikah massal secara ekonomis dapat dijual sebagai ajang dan bagian dari entertainment dan solusi menekan angka nikah siri, yakni munculnya program nikah massal yang dipepolerkan beberapa tahun belakangan terutama di kota-kota besar di Indonesia.

Akan tetapi perlu dipertanyakan umumnya peserta yang mengikuti program nikah massal, adalah pasangan yang telah menikah secara "de facto". Maksudnya pasangan secara agama dan kepercayaan telah sah sebagai suami isteri. Namun karena berbagai hal, seperti ketiadaan kemampuan ekonomi/biaya serta hilangnya akta nikah, maka pasangan yang telah menikah mengikuti program nikah massal. Artinya, peserta yang mengikuti program nikah massal tidak ada calon pasangan pengantin yang masih jejaka dan perawan.

Ide dan gagasan pelaksanaan nikah massal dapat memiliki tujuan dan manfaat yang baik, sepanjang dilakukan dengan semangat dan tatacara yang baik dan tidak melanggar ketentuan agama dan syariat Islam bagi penganutnya. Nikah massal sebagai model dan trend cenderung dilakukan bernuansa politis dan ekonomis, berpotensi menimbulkan pelanggaran baik hukum positif maupun hukum agama atau syariat Islam.

H. Nikah Siri menurut Hukum Islam

60 Nasir Jamil "Aspek Hukum Nikah Massal" dalam Republika, Sabtu 27 Februari 2010 
Secara agama, perkawinan tersebut sah, namun secara hukum, perkawinan ini tidak diakui resmi oleh negara. Dengan demikian, hak sebagai istri lemah secara hukum, apalagi jika status calon suami yang masih terikat perkawinan. risiko yang ditanggung, jika menikah siri:

1. Bisa kehilangan atau tidak dapat sepenuhnya hak-hak yang seharusnya bila jadi istri sah secara hukum, seperti hak nafkah lahir dan batin dan hak nafkah.

2. Seandainya terjadi perpisahan/talaq, maka istri tidak berhak atas tunjangan nafkah sebagai mantan istri dan harta gono gini.

3. Seandainya pasangan meninggal dunia, mantan isitri tidak berhak mendapatkan warisan.

4. Bisa terancam pidana. Istri sah dari suami (pelaku nikah siri) bisa saja melaporkan wanita pelaku korban nikah siri dan si suami telah melakukan tindak pidana kejahatan dalam perkawinan (pasal 279 (1) KUHP) atau tindak pidana perzinaan (pasal 284 ayat

(1) KUHP).

Secara hukum Islam, nikah siri merupakan perbuatan yang kurang menjaga kemaslahatan si istri dan anak. Karena bila saja si suami melakukan penelantaran nafkah si istri dan anak atau si suami meninggal, maka kemudian si istri tidak berdaya untuk mengadukan masalahnya kepada pihak berwajib atau perangkat hukum negara, semisal pengadilan dan sebagainya untuk diproses. Akibatnya si istri tidak menuntut penelantaran nafkah sekaligus tidak mendapatkan jatah warisan dari si suami bila meninggal dunia.

Hal itu karena si istri tidak mampu membuktikan bahwa si pria adalah suami sahnya. Oleh karenanya dengan adanya surat nikah maka sebenarnya menjaga kemaslahatan dan hak hukum si istri dan anak. Oleh karenanya dalam sudut pandang maslahah mursalah maka mencatatkan pernikahan menjadi wajib. Karena dalam dalam pencatatan nikah itu ada kemaslahatan. Selain dalam kewajiban tersebut ada upaya untuk menegakkan tujuan-tujuan syariat, yaitu menjaga kehormatan.

\section{Hasil Penelitian}

Hasil penelitian menunjukkan bahwa masyarakat melakukan nikah di kabupaten Pamekasan karena : Berkeyakinan bahwa biaya nikah mahal, rumitnya mengurus administrasi pernikahan, Nikah siri 
karena dianggap sudah sah menurut hukum masing-masing agama dan kepercayaannya termasuk ketentuan perundang-undangan yang berlaku.

\section{Daftar Pustaka}

Ahmad, Nada Abu, Engkaulah Pendamping Yang Aku Cari, Solo: Pustaka Iltizam, 2007

Al-Aini, Badruddin, Umdah al-Qariy Syarhu Shahih al-Bukhariy, al-Maktabah al-Syamilah, tt

Al-Anshari, Zakariya, Hasyiyah al-Jamal, al-Maktabah alSyamilah, $\mathrm{tt}$

Al-Asqalaniy, Ibnu Hajar, Bulugh al-maram Min Adillati alAhkam, Surabaya : al-Hidayah, tt

Al-Baidlawi, Tafsir al-Baidlawi, al-Maktabah al-Syamilah, tt

Al-Bajuri, Ibrahim, Hasyiyah al-Bajuri Ala Ibn Qosim, Surabaya : al-Hidayah, tt

Al-Bujairimi, Hasyiyah al-Bujairimi al al-Khatib, al-Maktabah alSyamilah, $\mathrm{tt}$

Al-Bukhari, Muhammad ibn Ismail, Shahih al-Bukhari, alMaktabah al-Syamilah

Surabaya

Al-Dimyati, Muhammad Syatha, I'anah al-Thalibin, al-Hidayah

Al-Husaini, Abu Bakar Muhammad, Kifayah al-Akhyar, alMaktabah al-Syamilah, tt

Al-Kurdy, Muhammad Amin, Tanwir al-Qulub Fi Mu'amalah 'Allamil Uyub, Jakarta : an-Nur, tt

Al-Mahally, Jalaluddin Muhammad dan al-Suyuty, Jalaluddin Abdur Rahman, Tafsir al-Qur'an Lil Imamaini al-Jalalaini, Indonesia : Dar Ihya' al-Kutub al-Arabiyah, tt;

Al-Malibari, Zainuddin, Fath al-Mu'in, Surabaya : al-Hidayah, $\mathrm{tt}$

Al-Mawardi, Ali ibn Muhammad, al-Nukat wa al- 'Uyun, Maktabah al-Syamilah, tt

Al-Nawawi, Raudlah al-Thalibin Wa 'Umdah al-Muftin, alMaktabah al-Syamilah, tt

Al-Thabari, Imam, Tafsir al-Tabari, al-Maktabah al-Syamilah, tt 
Al-Zamakhsyari, Tafsir al-Kasysyaaf, (al-Maktabah al-Syamilah, $\mathrm{tt}$

'Athiyyah, Jamaluddin, Nahwa Taf'il Maqashid al-Syariah, Dar al-Fikr, Damaskus, 2001

Baharun, Hasan, Islam Esensial: Kajian Membumikan Sunnah Rasulullah, Jakarta : Pustaka Awam, 1998

Bisri, Adib \& Munawwir, Kamus al-Bisri, Surabaya : Putaka Progresif, 1999

Chafidh, M. Afnan dan Asrori, A. Ma'ruf, Tradisi Islami, Surabaya : Khalista, 2006

Departemen Agama, Al-Qur'an dan Terjemahnya, Bandung : alJumanatul Ali, 2005

Ibn al-Asy-'ab, Sulaiman Abu Dawud, Sunan Abu Dawud, alMaktabah al-Syamilah, $\mathrm{tt}$

Ibn Hajjaj, Muslim, Shahih Muslim, al-Maktabah al-Syamilah, tt

Ibn Isma'il, Muhammad, Subul al-Salam, al-Maktabah alSyamilah, $\mathrm{tt}$

Kementerian Wakaf dan Urusan Agama Kuwait, al-Mausu'ah al-Fiqhiyyah, al-Maktabah al-Syamilah, tt.

Manan, Bagir, Keabsahan dan Syarat-Syarat Perkawinan antar orang Islam menurut UU No. 1 Tahun 1974, makalah disampaikan dalam Seminar Nasional dengan tema Hukum Keluarga dalam Sistem Hukum Nasional antara Realitas dan Kepastian Hukum, yang diselenggarakan Mahkamah Agung Republik Indonesia, di Hotel Redtop, pada hari Sabtu, tanggal 1 Agustus 2009

Muhammad, Abdulkadir, Hukum dan Penelitian Hukum, Bandung, Citra Aditya Bakti, 2004

Jamil, Nasir, "Aspek Hukum Nikah Massal" dalam Republika, Sabtu 27 Februari 2010

Tim penyusun, Kompilasi Hukum Islam, Instruksi Presiden Nomor 1 Tahun 1991

Yayasan Lembaga Bantuan Hukum APIK Jakarta, Pentingnya Pencatatan Perkawinan, diakses dari http://www.lbhapik.or.id/fact-14\%20penct.\%20perkawinan.htm, pada tanggal 08 April 2011. 